\title{
NOTES ON SPATIAL-STRUCTURAL CHANGE IN URBAN SOUTH AFRICA -THE 1990S
}

\author{
Hermanus S. GEYER \\ Stellenbosch University, South Africa
}

\begin{abstract}
Informal businesses used to be something that was only tolerated in the former black townships during the years of apartheid. Since then the informal business sector has become an integral part of the central business setup of cities in South Africa. It not only serves to widen the security net of the urban poor in cities, it also represents the outcome of the democratization process in the country over the past fifteen years. Yet, there has been a tendency amongst local authorities to take steps to reduce the footprint of this sector in the urban environment in recent years. This trend ties in with the new approach of government to transform South African cities to become 'world class' centres - a step that is aimed at making the cities more visually acceptable to visitors from abroad. In this paper an attempt is made to demonstrate the importance of the informal sector within the urban business makeup and to show what role it played in the spatial-structural evolution of the urban economies during the 1990s. The paper analyzes the structure of the urban business sector as a whole and structurally links the formal and informal sectors, demonstrating the importance of both sectors in the economic makeup of the cities. It analyses the structure of the informal sector and shows how different layers of the sector potentially relates to the formal urban sector.
\end{abstract}

Key Words: Informal sector, formal sector, business anatomy, economic structure

\section{Introduction}

This paper deals with changes in the focus of business development and the business climate in South Africa before and after the political take-over. It discusses the impact these changes had on the business structure of urban areas all over South Africa since the political takeover in 1994.

\section{The history of entrepreneurship in South Africa}

Entrepreneurship essentially deals with the way in which business is conducted. It deals with potential of conducting, expanding or improving the quality of business and methods how to achieve those goals. Innovation is a central theme in entrepreneurship. For many years not all the population groups enjoyed equal opportunities in the development of business skills in South Africa (Geyer, 1989a; 1994). Through the policy of apartheid the black population groups were particularly disadvantaged and as a result the levels of development of entrepreneurship amongst the population groups became severely skewed over the years. The lack of opportunities given to the black groups to develop their entrepreneurial skills is clearly indicated in Figure 1 (Geyer et al., 2000). The figure shows how the economic areas of urban centres that were located in former white controlled areas were much more developed than those of urban areas located in black areas. 


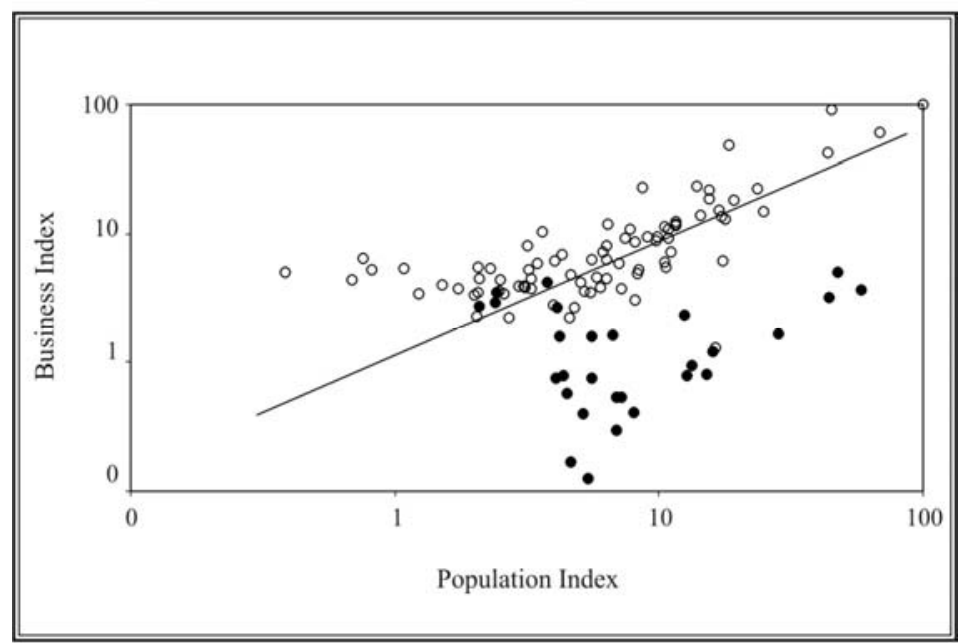

Fig. 1 - Provision of services in a selection of SA urban centres, 1996 (Source: Own calculations, 1996)

The human activities model (Figure 2, Geyer, 2001, 2002b) portrays the layers of possible social and economic activities in any given area. Depending on global, national and local market conditions each layer holds the potential for a variety of business activities (Geyer 2002a). For many years the black population were only allowed to participate fully in all layers of activities

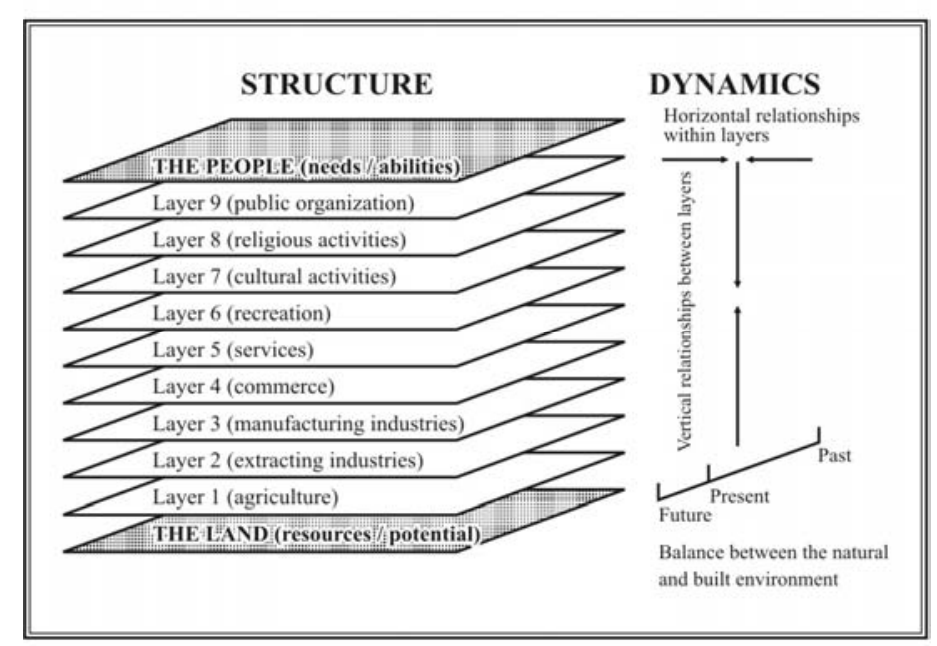

Fig.2 - A human activity model (Source: Geyer,2001) 
in the Bantustans. In white controlled areas they were not allowed to own businesses in the first three layers of the model and in the initiation of activities in the other layers they were limited to designated black residential areas.

In addition to these negative local conditions global forces also impeded the development of entrepreneurship in South Africa

\section{Globalization}

Changing divisions of labour. During the colonial era manufacturing occurred mostly in First World states while the colonized states served as sources of raw material, expanding markets for produced goods, and receptor areas for excess labour. During this period production and trade in the latter revolved around the primary sector. This led to the first international division of labour of the twentieth century.

When the colonial era ended after World War II the South African government started concentrating on import substitution which reduced the country's level of specialization and at the same time its competitiveness in areas in which it had a competitive advantage. Increasing labour costs in the First World and comparatively low labour costs and high levels of productivity in certain peripheral countries triggered post-Fordism and led to global industrial sprawl - the second international division of labour. Newly industrialized countries benefited mostly by the evolving second division of labour.

Global political changes in the 1980s, but particularly during the 1990s when Second World economies in Europe were liberated, led to the formation of global super power blocks. Western and Southern Europe started concentrating on their own human and market potential and those of the liberated Central European nations, North America on its Latin American neighbours and Japan on its neighbours in the Pacific Rim (Lipietz, 1997; Geyer, 2006), while global regions such as Central and Southern Africa were lagging behind (Geyer and van der Merwe, 2006). This brought about the current third international division of labour.

How Africa relates to globalization. The developing countries in East and South East Asia which responded early to the potential advantages that the second phase of international division of labour held, benefited the most from the global industrial sprawl. Africa did not. Although South Africa had the ability to keep pace with the developed world in almost all respects, and for most part did, especially amongst the whites, the rest of Africa south of the Sahara has been lagging behind. The most important reasons for this backlog include the following:

Locational disadvantages. Although historically, almost the entire Africa had colonial ties with Europe, strained relations with colonial powers after independence - much of them linked to their growing resistance to neo-liberalism and subsequent acceptance of static socialist policies - caused most African countries to struggle economically. More recently, in an era of global regionalization, locational disadvantages has exacerbated the situation.

Negative human development conditions. With only 16 doctors per 1000 of the population compared to 253 per 1000 in developed countries; an illiteracy rate of 41 per cent; and only 58 per cent of people having access to safe water, human development conditions are stacked against people in Africa. The result: a life expectancy at birth of 48.9 years compared with 77.7 years in developed countries and a mortality rate of juveniles of 169 per 1000 compared with 7 
per 1000 in the developed world (Nepad, 2001).

A lack of infrastructure. Africa is also struggling with infrastructure. While there are 567 telephones per 1000 people in the developed world, there are only 18 lines per 1000 people in Africa. The improvement of communication infrastructure is also hampered by relatively high service provision costs in Africa-20 per cent of GDP per capita, compared to the world average of 9 per cent and 1 per cent in developed countries (NEPAD, 2001).

Crime and violence. Internal strife is a trademark of African politics. Economic hardship is more often than not an underlying cause.

Inward-looking economic policies with negligible attachments to the global economy. New African initiatives such as the New Partnership for Africa's Development (NEPAD) has done little to change the First World's apprehension about Africa's inability to transform itself economically and politically. Instead it has a wait and see attitude. In contrast, the newly industrialized economies of Asia such as Hong Kong, Indonesia, Japan, Malaysia, Singapore, South Korea, Taiwan and Thailand have been maintaining high economic performances for many years. This is because, on the one hand, they were able to consistently keep their levels of investment in education high to boost productivity and, on the other hand, have kept interest rates down to stimulate capital investment (Marshal, 1995)

Extreme levels of poverty. Half the African population lives on less than $\$ 1$ per day, a factor that is impeding the population's ability to increase its productivity levels.

Scepticism amongst developed countries about the capacity of Africa to perform. Generally, African countries have been heavily dependent on development aid since their independence but, with few exceptions, have not been able to impress as development initiators and innovators.

Although South Africa is better off than most other African countries in almost all the departments listed above (accept for its high levels of unemployment lately and the concomitant high levels of crime and violence) it is against this negative background that entrepreneurship has to be nurtured in South Africa.

\section{Changes in the urban business sector in South Africa}

The anatomy of the business sector. Figure 3 serves as a diagrammatic representation of the anatomy of the business sector in South Africa. It refers to the following elements of the business sector:

the sizes of businesses,

types of business,

$\square$ their sectoral reach,

class of businesses,

their levels of sophistication,

their location,

their reach, and

口 ways of communications

This figure enables one to trace the changes that have taken place in the business sector in South Africa over the years. Relative shifts in the balance of business sizes and between the 
formal and informal sectors allow one to assess the ability of the business sector to compete in the global market at different time periods (Geyer, 2002a).

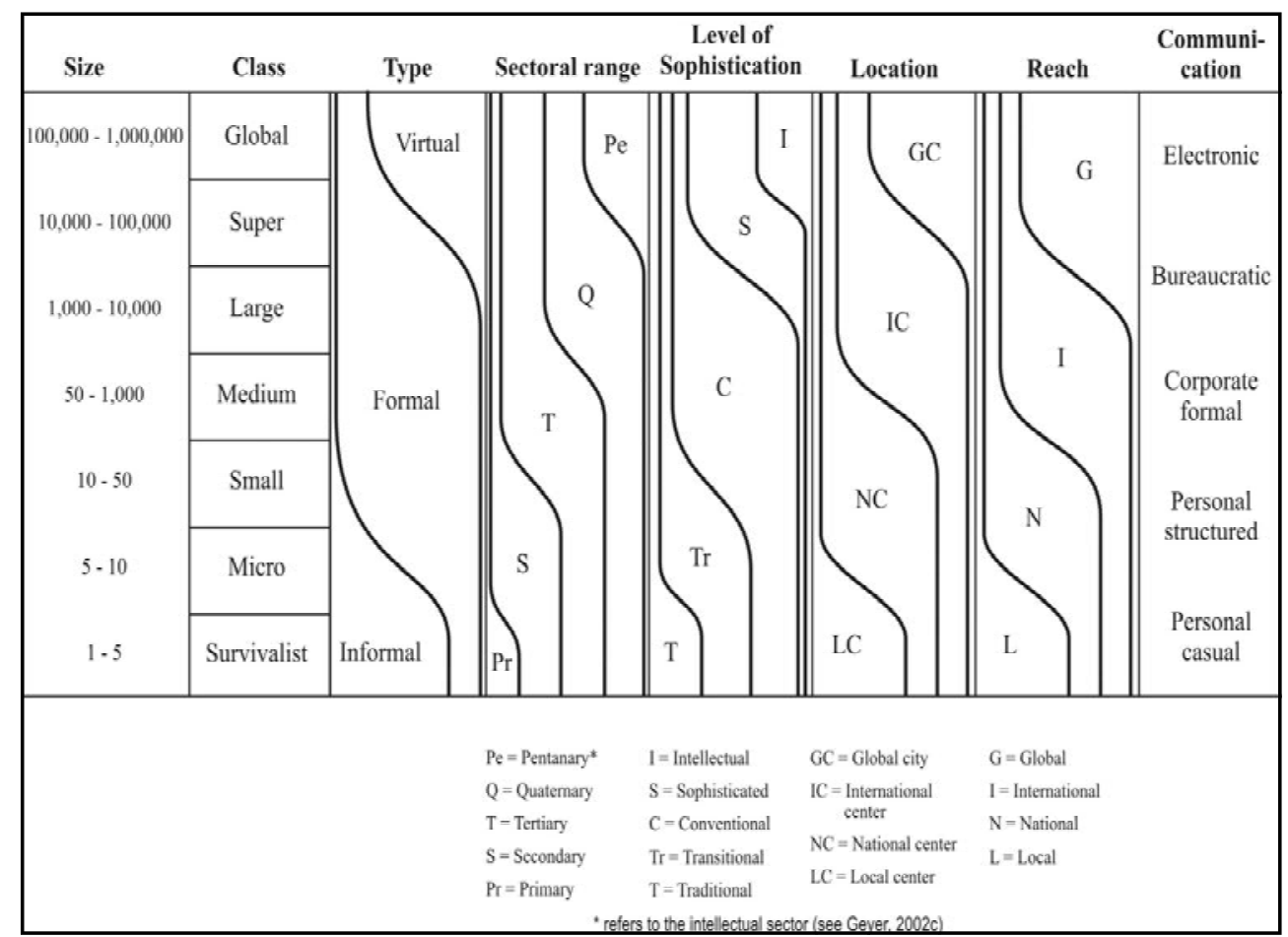

Fig. 3 - Anatonomy of business sector

Changes during the apartheid era. Although non-white people were prevented from meaningful participation as entrepreneurs during the years of apartheid a number of important changes occurred in the business sector in South Africa during the period which boosted small business development:

- Protectionism in 1950s, assisted by boycotts during the 1960s and 70s caused the blossoming of local businesses. White small business owners were particularly advantaged by the sanctions while small black owned businesses were prevented from opening up businesses in what were regarded as 'white' urban areas.

During the 1970s the development of American-styled local franchised businesses began to become fashionable in South Africa. Large, divisional shops which offered wide ranges of groceries and household goods sprang up in towns and cities of all sizes all over the country. This lead to a decline in the clients of traditional small single owner general businesses in urban centres, especially in smaller towns.

․ By the early 1990s, when it became clear that apartheid was coming to and end the gradual opening up of the South African market to the world outside lead to an increase in the range of franchised businesses. The result was a dramatic increase in production lines and in the variety 
of outlets. Many local small businesses tapped into the new production lines that became available in the global market. ${ }^{1)}$

- The opening up of trading opportunities as a result of the relaxation of petty apartheid policies which prevented black entrepreneurs from participating in urban economies caused many black entrepreneurs to enter the informal business sector. Initially, these traders were mostly concentrated in black residential areas, as they were during the years of apartheid. However, the relaxation of trading regulations and the scrapping of trading restrictions in areas that were previously prohibited for blacks caused this sector to spill over into the central city areas.

The changing economic morphology since the mid-1990s. Over-urbanization is a well-known phenomenon all over the world, especially in developing countries (Gugler, 1990). Features that are generally associated with the process include unemployment, underemployment ${ }^{2)}$ and misemployment ${ }^{3)}$. Although the forms of over-urbanization that started to manifest itself in urban South African since the mid-1990s are far from uniform, few cities, if any, managed to completely escape the effects of the phenomenon. They are:

a. large flows of lowly skilled (mostly black) migrants to cities;

b. an increase in competition in the manual labour sector;

c. an inability of many of the new in-migrants to effectively compete for employment in the formal urban sector;

d. rising crime levels, underemployment and misemployment in cities overall;

e. the continuation of the apartheid urban morphological growth model, i.e. (parts of) city centres loosing momentum (but now faster than before) while the poor continue to live on the outskirts of urban areas and higher income groups in the suburbs (Geyer, 1993);

f. parts of former predominantly white residential areas becoming predominantly black;

g. an increase in informal urban activities in central urban areas;

h. a decrease the number of higher income shoppers in parts of city centres; and

i. capital flight from central city areas to the outlying residential areas.

Generally, these trends held significant consequences for urban South Africa, notably the spatial-economic restructuring of cities. Informality increased in parts of cities where only the formal sector used to trade causing the formal businesses there to adapt to changing markets and trading conditions. In certain central city areas - Pretoria, Johannesburg, and Durban in particular - the effects of these changes were significant. In others the negative effects of the change were less significant, even largely averted - such as Cape Town. In cases where the negative effects of over-urbanization in central city areas were severe six clearly distinguishable trends were visible:

a. the economic deterioration of parts of CBDs coupled with an increase in informal activities in those areas;

b. the development of new shopping centres or the revival of existing shopping centres in parts of CBDs;

c. the transformation of the fringes of CBDs from residential into business zones;

1) Similar changes have been observed in Turkey in recent years (Nebahat and Yonca, 2002; Zoltan, et al., 2001)

2) Underemployment refers to the underutilization of labour, i.e. when not all the labour is being utilized optimally, such as part time employment.

3) Misemployment refers to labour that is occupied but the activities do not contribute positively to social welfare, such as prostitution, and burglary. 
d. The development of new business corridors along main transport corridors leading towards CBDs, or routes connecting CBDs with major business zones elsewhere in the cities;

e. the development of new up-market shopping centres in suburban nodes that are regraded as safer and economically more viable locations for higher income shopping; and

f. the location of specialized commercial and service businesses inside residential areas.

\section{Possible reasons for the spatial-economic transformations}

Premature economic deterioration of parts of the $C B D$. Reasons for the premature deterioration of parts of the CBDs of cities could be ascribed to the following factors:

a. large scale infiltration of informal businesses into those parts of the CBDs;

b. the deterioration of the built environment, physically and socially; and

d. a decline in the number of high income shoppers.

Economic concentration within the $C B D$ and suburbs. Businesses started leaving negatively effected areas of CBDs and moved to secured shopping centres elsewhere in the central business areas or suburban areas. In smaller urban areas where demand in suburbs were not sufficient, large shopping centres tended to develop inside the CBDs. The reasons for the relocation of businesses to the shopping centres are the following:

a. a lack of security in negatively affected parts of the CBD;

b. easier secured parking close by shopping facilities;

e. shopping safety;

f. protection against the elements;

g. one-stop shopping; and

h. the entertainment value of shopping at shopping centres.

Economic sprawl along the CBD fringe. Some specialized commercial and service functions tended to move towards the fringes of CBDs. Reasons that were usually given for the relocation to home conversions along the $\mathrm{CBD}$ fringe are the following:

a. a lack of security in the CBD;

b. a decline in the number of customers in the CBD;

c. the availability of low cost residential buildings in the zone of urban decay along the fringes of the CBDs;

d. lower rents;

e. greater financial security;

f. the possibility of creating a more professional, cosy, intimate, or other specialized business atmosphere; and

h. safe parking close-by.

Economic corridor development. Certain specialized commercial and service functions tended to relocate from inside the $\mathrm{CBD}$ to the locations along major traffic arterials. Intra urban development axis forces play an important role in the corridor development along major collector routes in cities (Geyer, 1987, 1989d). Most of the factors that cause economic sprawl also apply to businesses that relocate to transport corridors. Additional factors that cause this phenomenon are:

a. the increased visibility of sites from main collector roads; and

b. the need of businesses for greater access to a larger number of vehicles.

Economic decentralized concentration. Certain previously deteriorating suburban shopping centres have been showing new signs of life and several new centres have sprung up in 


\begin{tabular}{|l|l|l|l|}
\hline SECTOR & LOCATION & SIZE & SOPHISTICATION \\
\hline Formal & $\begin{array}{l}\text { City centre } \\
\text { Traditional } \\
\text { Security shopping centre } \\
\text { City centre fringe sprawl } \\
\text { Suburban centre } \\
\text { Corridor between nodes } \\
\text { Inside residential area }\end{array}$ & $\begin{array}{l}\text { Small to } \\
\text { large }\end{array}$ & Low to high \\
\hline 2. Industrial & $\begin{array}{l}\text { Industrial area } \\
\text { Urban fringe }\end{array}$ & $\begin{array}{l}\text { Small to } \\
\text { large }\end{array}$ & Low to high \\
\hline
\end{tabular}

\begin{tabular}{|l|l|l|l|}
\hline Semi-informal & $\begin{array}{l}\text { City centre } \\
\text { Side walks } \\
\text { Parks } \\
\text { Main road junctions }\end{array}$ & $\begin{array}{l}\text { Small to me- } \\
\text { dium }\end{array}$ & Low to high \\
\hline 2. Industrial & $\begin{array}{l}\text { Residential area } \\
\text { Main road junctions }\end{array}$ & $\begin{array}{l}\text { Small to me- } \\
\text { dium }\end{array}$ & Low to high \\
\hline
\end{tabular}

\begin{tabular}{|l|l|l|l|}
\hline Transitional (informal) & $\begin{array}{l}\text { City centre } \\
\text { Side walks } \\
\text { Parks }\end{array}$ & $\begin{array}{l}\text { Small to me- } \\
\text { dium } \\
\text { Main roads } \\
\text { Stop streets } \\
\text { Junctions }\end{array}$ & Low to medium \\
& $\begin{array}{l}\text { City centre } \\
\text { Side walks } \\
\text { Parks } \\
\text { Residential areas }\end{array}$ & $\begin{array}{l}\text { Small to me- } \\
\text { dium }\end{array}$ & Low to medium \\
\hline 2. Services & $\begin{array}{l}\text { Residential area } \\
\text { Main road junctions }\end{array}$ & $\begin{array}{l}\text { Small to me- } \\
\text { dium }\end{array}$ & Low to medium \\
\hline
\end{tabular}

\begin{tabular}{|l|l|l|l|}
\hline Traditional (informal) & $\begin{array}{l}\text { City centre } \\
\text { Side walks } \\
\text { Parks } \\
\text { Main road junctions }\end{array}$ & Small & Low \\
\hline 2. Services & Residential area & Small & Low \\
\hline 3. Industrial & $\begin{array}{l}\text { Residential area } \\
\text { Main road junctions }\end{array}$ & Small & Low \\
\hline
\end{tabular}

\section{Fig. 4 - Hypothetical structure of the informal economic sector in urban SA and how it ties in with the formal sector}

suburban areas during the 1990s. Apart from the positive impact that the deterioration of CBDs or parts of them had on the revival of suburban shopping centres in cities, other reasons for their survival included:

a. greater accessibility from people's homes in suburbs;

b. higher levels of security than in traditional shopping streets in CBDs; and 
c. greater financial security for tenants and property owners.

Isolated economic decentralized activities. Certain highly specialized economic activities such as art galleries, specialized clock repair services, specialized jewel sales, and professional services tend to relocate to higher income residential areas. These relocations are possible because:

a. such activities often target a relatively small but lucrative market; and

b. security is a priority, but

c. accessibility is not.

Stratification of the informal sector. Initially, the distribution of informal businesses in black neighbourhoods seemed to have had an amorphous structure. Businesses seemed to have been haphazardly distributed. But since the dramatic increase in the number of informal businesses and especially since it became more widely distributed throughout the cities it started attaining an ordered structure. Three distinct layers of informal businesses that structurally tie into the formal urban economic sector (see Figures 4) are now discernable (Geyer, 1989c). At the bottom is the traditional economic layer of activities. These activities are more or less associated with traditional ways of preparing food, producing goods, and providing social, health and financial services to the traditionally oriented segments of society. The transitional layer consists of traditionally oriented activities that have undergone significant innovations to also accommodate the more modern ideas, customs and needs of urban communities. At the top there are the semi-formal activities. Products that are offered in this layer are by and large more sophisticated and technologically advanced goods and services that are put on offer on the informal urban market. Many of these goods and services are also available in the formal sector, but at much reduced prices since overhead costs are lower. They also include cheap manufactured goods that originate mostly from the Pacific Rim - an example of how, as indicated on Figure 3, globalization also impacts on the lower levels of urban economic activities.

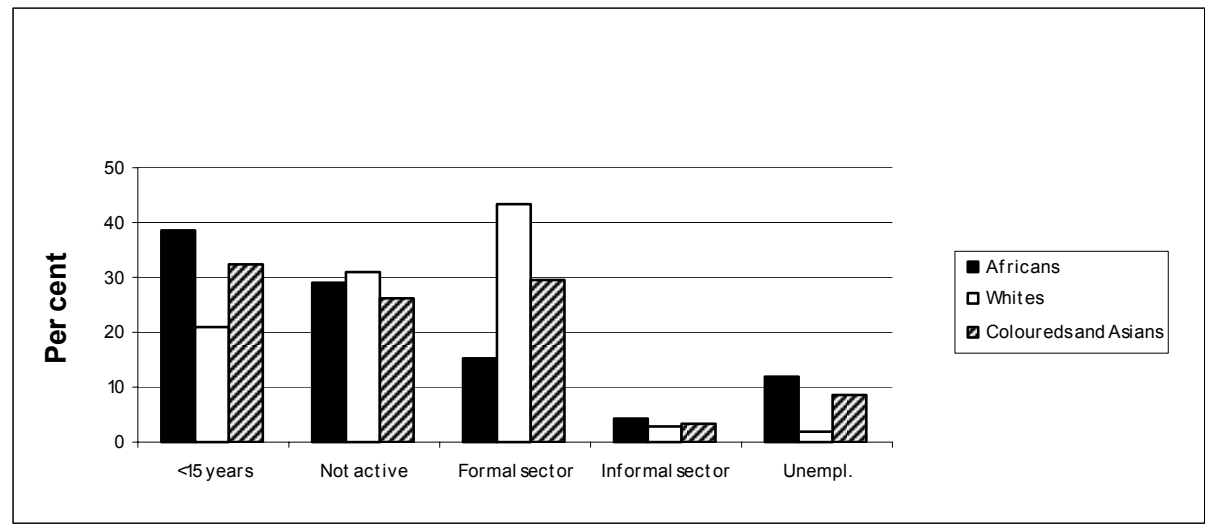

Fig. 5 - Economic participation by population group, SA 1995 The business profile of South Africa during the mid-1990s

As could have been expected, a larger proportion of the white population group was employed in the formal economic sector during the mid-1990s while larger proportions of the black population group were active in the informal sector (see Figure 5). Although there were much less large and medium-sized firms in the country (Figure 6), they provided most of the 
employment opportunities (Figure 7).

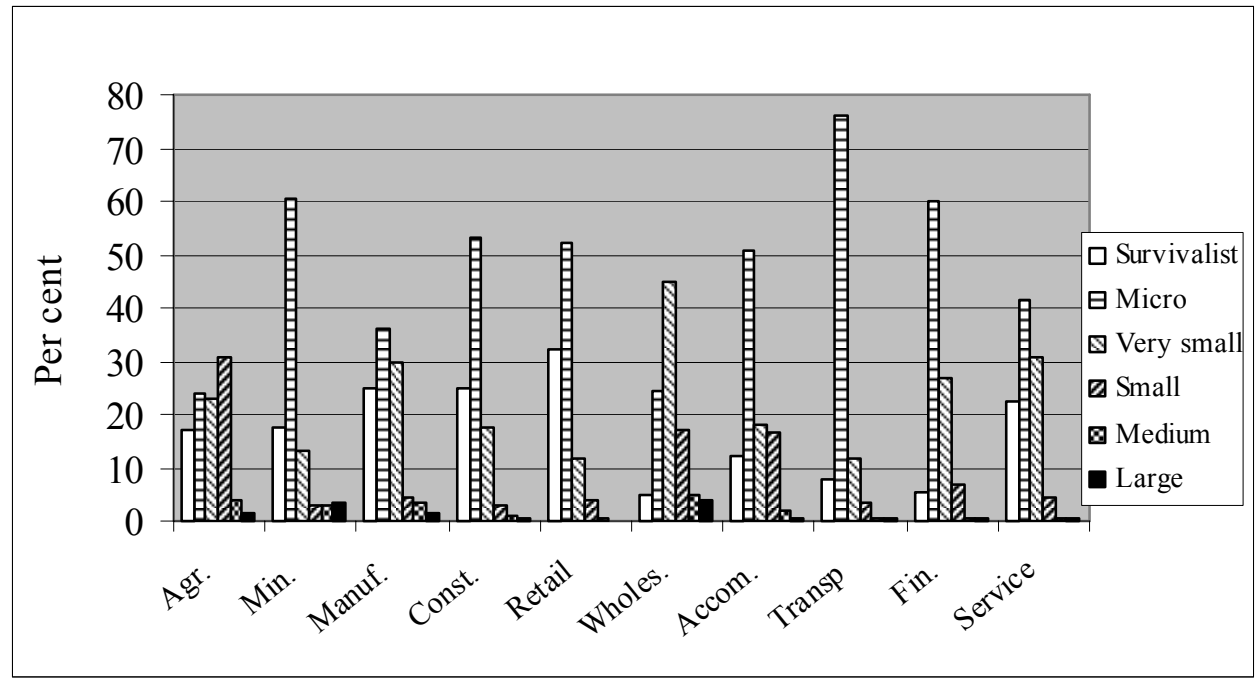

Fig.6 - Distribution of private enterprises per economic sector, SA 1995

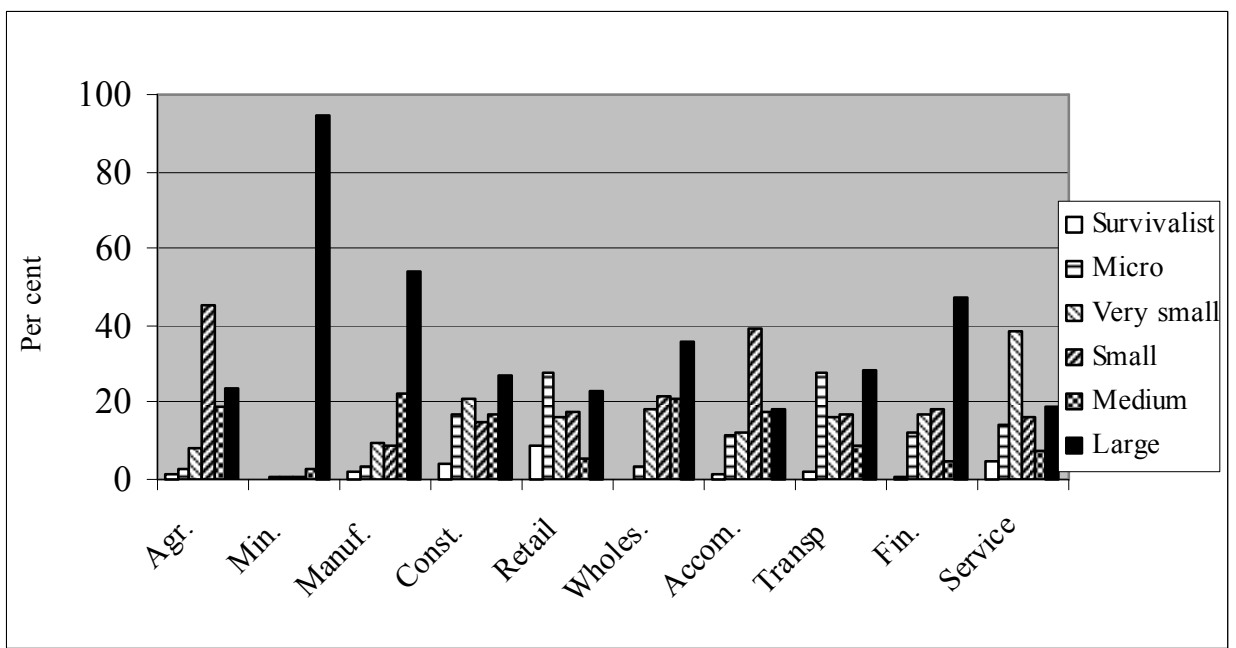

Fig.7 - Distribution of employment, SA 1995

Most entry level businesses - i.e. survivalist businesses and micro businesses that did not provide any employment other than for the business undertaker him/herself - were located in the informal settlements (Figure 8). In accordance with Figure 8, the highest percentage of large and medium-sized business in Figure 9 were found in the provinces where large metropolitan areas are located, i.e. Gauteng (GT), KwaZulu-Natal (KN), and the Western Cape (WC), while a larger percentage of businesses at the entry level were located in the more rural provinces of the country, i.e. the Eastern Cape (EC), Northern Province (NP), the North West province (NW), Mpumalanga (MP) and the Free State (FS). 


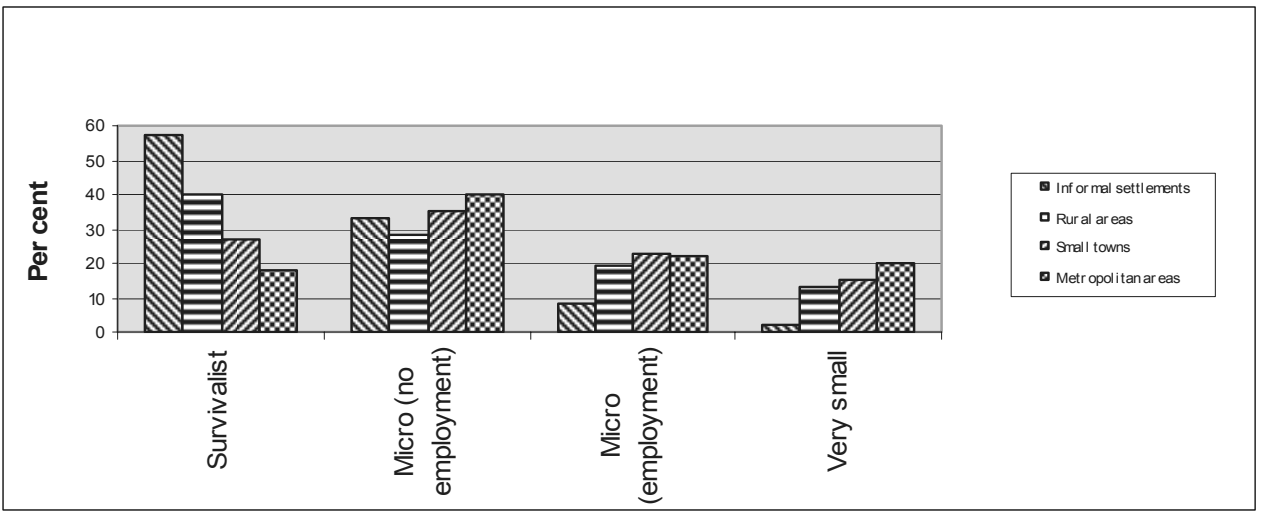

Fig. 8 - Enterprise by locality in SA, 1995

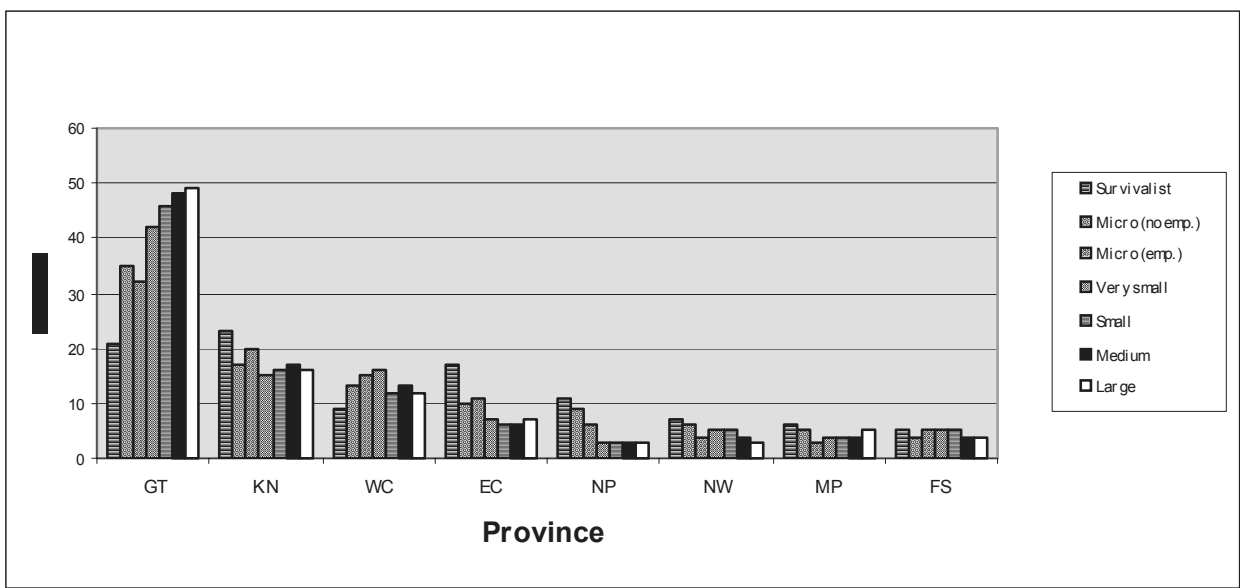

Fig. 9 - Enterprise by province, 1995

In recent years a number of business actors and activities, focussing on the small business sector, have been established at all levels of decision making. These include the current National and Provincial Small Business Councils as well as economic and business centres of various kinds at the local government level. Diagrammatically, the current structure of organized business at the formal and informal sectors is shown in Figure 10. Although the links between the formal and informal sectors that are shown in the figure are not working well in all areas, the potential for such links are nevertheless there.

\section{Conclusions}

A significant proportion of the South African population never had sufficient opportunities to properly develop their abilities as entrepreneurs during the years of apartheid. Since democracy has been restored significant changes have occurred in the economic structure of cities. 


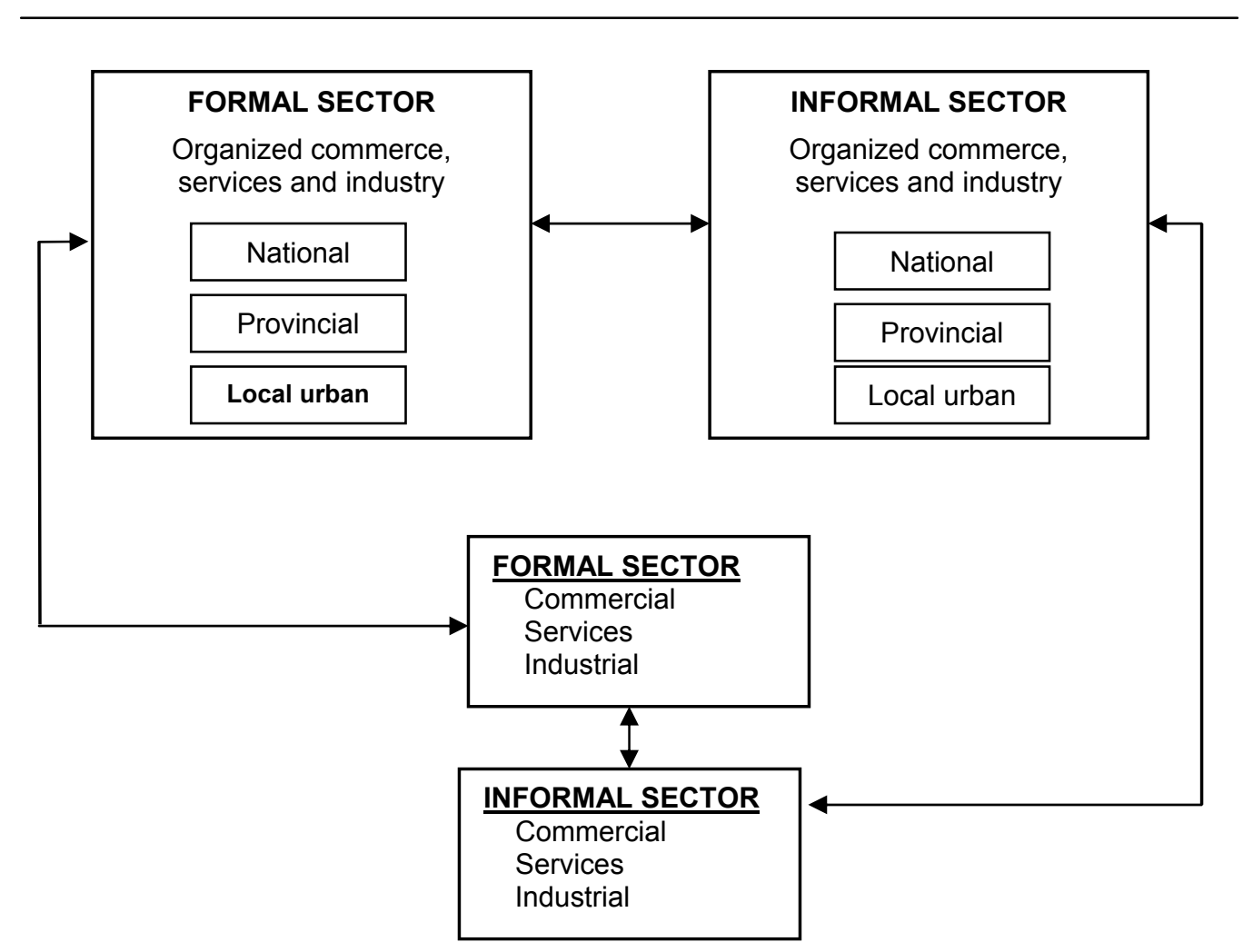

Fig. 10 - Link between the formal and informal urban economic sectors in SA

In the country. In this study changed that have occurred during the early years of democracy has been studied. The huge inflow of migrants from rural areas that were experienced in cities at the time lead to an unprecedented increase in informal economic activities in urban areas of all sizes. This has put in motion a train of related structural changes. While the informal sector had gained ground in parts of the central business districts of cities causing a change in the character of central city areas there, business that have remained in such areas had to reorientate themselves to cater for the changing market. Others simply moved. Some of the latter moved to the fringes of CBDs transforming old residential areas into new business zones. Others moved to security shopping centres inside the CBDs, or established themselves along main roads leading away from the CBD, or moved to security shopping centres inside the suburbs.

This business structure that have become cemented over the past fifteen years is a product of the political democratization process in South Africa. Informal activities are an integral part it. Steps that are currently being taken by local governments to marginalize the informal sector in their new drive to transform urban areas into 'world class' cities and to make them more 'presentable' to foreign visitors, are harming the informal business sector significantly. As a sector that contributes hugely to the widening of the survival net of the urban poor, this trend could make it increasingly difficult for many of these people to survive in South African cities in the future. 


\section{References}

GEYER H.S. (1987), The development axis as a development instrument in the Southern African development area, Development Southern Africa, 4, p.271-301.

GEYER H.S. (1989a), Industrial development policy in South Africa - The past, present and future, World Development , 17, p.379-396.

GEYER H.S. (1989b), The integration of the formal and informal urban sectors in South Africa, Development Southern Africa, 6, p. 29-42.

GEYER H.S. (1989c), The terminology, definition, and classification of development axes, The South African Geographer, 16, p. 113-129.

GEYER H.S. (1993), African urbanization in metropolitan South Africa - differential urbanization perspectives, GeoJournal, 30, p. 301-308.

GEYER H.S. (1994), Development ideology and the political transition in South Africa changing perspectives, Planning Perspectives, 9, p. 377-404.

GEYER H.S. (2001), Development planning transition in South Africa, In H. C. Marais, Y. Methien, N.S. Jansen van Rensburg, M.P. Maaga, G.F. de Wet, C.J. Coetzee (eds), Sustainable social development: Critical dimensions. Pretoria: Network Publishers, p.143-152.

GEYER H.S. (2003), South Africa in global context: the view from above and below,

Annals of Regional Science, 37, p. 407-420.

GEYER H.S. (2002), The fundamentals of urban space, in H. S. Geyer (ed.) International handbook of urban systems: studies of urbanization and migration in advanced and developing countries, Edward Elgar, Cheltenham, Aldershot, UK, p.3-18.

GEYER H.S. (2006), Introduction: the changing global economic landscape, in H. S.

Geyer (ed.) Global Regionalization: Core-peripheral migration and economic trends, Edward Elgar, Cheltenham, Aldershot, UK, p.3-40.

GEYER H.S., van der Merwe I.J. (2006), Sub-Saharan Africa - a region economically delayed (ed.) Global Regionalization: Core-peripheral migration and economic trends, Edward Elgar, Cheltenham, Aldershot, UK, p.187-224.

GUGLER J. Overurbaniztion reconsidered, in Gugler, J. (ed.) The urbanization of the Third World, Oxford University Press, London, p.74-92.

LIPIETZ A. (1997) The post-Fordist world: labour relations, international hierarchy and global ecology. Review of International Political Economy, 4: 1-41.

MARSHAL R. (1995), The global job crisis, Foreign Policy, No.100, p. 50-68.

NEPAD (2001), New Partnership for African Development, www.polity.org.za/misc/ mapomega.html.

SOUTH AFRICA (1995) Household survey, Central Statistical Services, Pretoria.

TOKATLI N., ELDENER B. (2002), Globalization and the changing political economy of distribution channels in Turkey, Environment and Planning A, 34, p. 217-238.

ZOLTAN J. A., MORCK R. K., YEUNG B. (2001), Entrepreneurship, globalization and public policy, Journal of International Management, 7, p. 235-251. 